\title{
ZAKAT AND SDG 6: A CASE STUDY OF BAZNAS, INDONESIA
}

\author{
Fahmi Ali Hudaefi ${ }^{1}$, Abdul Aziz Yahya Saoqi ${ }^{2}$, \\ Hidayaneu Farchatunnisa ${ }^{3}$ and Ulfah Lathifah Junari ${ }^{4}$ \\ ${ }^{1}$ Institut Agama Islam Darussalam (IAID) Ciamis and BAZNAS \\ Center of Strategic Studies, Indonesia, alihudzaifi@gmail.com \\ ${ }^{2}$ BAZNAS Center of Strategic Studies, Indonesia, aziz.saoqi@puskasbaznas.com \\ ${ }^{3}$ BAZNAS Center of Strategic Studies, Indonesia, hidayaneu.farchatunnisa@puskasbaznas.com \\ ${ }^{4}$ BAZNAS Center of Strategic Studies, Indonesia, ulfah.lathifah@puskasbaznas.com
}

\begin{abstract}
Recent zakat distribution by the National Board of Zakat, Republic of Indonesia (BAZNAS), such as the construction of private lavatories for underprivileged households, have contributed to the idea that zakat promotes the sustainability of clean water and sanitation (SDG 6). However, this notion demands detailed academic explanation to better understand it systematically. This paper thus aims to explore the degree to which the toilet construction project has benefitted its recipients. This case study of BAZNAS's project in Kendel, Boyolali, Indonesia, employs a qualitative approach based on participatory observation and semi-structured interviews. The findings explain the perspectives of local community after receiving the assistance, including the identification of reduction in numbers of local people affected by diarrhoea. This information may validate the relationships between health, water and sanitation. Furthermore, the findings capture the involvement of local government in the project execution. Thus, social and practical implications are revealed by this study. This study pioneers the establishment of scholarly-based evidence about the programme of individual toilet construction executed by BAZNAS, and about the perspectives of its recipients in the wake of receiving the aid.
\end{abstract}

Keywords: BAZNAS, Zakat, SDGs, Water, Sanitation, Indonesia.

JEL Classification: I19; I31; R19; Z120.

Article history:

Received : November 4, 2019

Revised : August 25, 2020

Accepted : August 27, 2020

Available online : November 25, 2020

https://doi.org/10.21098/jimf.v6i4.1144 


\section{INTRODUCTION}

\subsection{Background}

In Islam, zakat (almsgiving) is a religious obligation that takes the form of wealth payments in which payers and recipients are governed by the Quran (Abdullah \& Suhaib, 2011). The primary aim of zakat is to protect the sustainability of the basic needs of underprivileged people and to improve their quality of life (Abd. Wahab, Zainol, \& Abu Bakar, 2017). This fundamental of zakat, to some degree, has a substantial role to implement the first two United Nations Development Programme (UNDP) Sustainable Development Goals (SDGs) of zero poverty and no hunger (SDGs 1 and 2) in Muslim majority countries.

In Indonesia, the National Board of Zakat, known locally as Badan Amil Zakat Nasional (BAZNAS), has been playing a pivotal role in zakat distribution programmes and its current practices in distributing zakat funds have evolved considerably. One of the innovative BAZNAS programmes which aims to improve the quality of life of underprivileged people is assistance with the construction of individual lavatories. To some extent, this project has been a way of promoting SDG 6 - clean water and sanitation. In light of innovative distributions of zakat such as this programme, evidence is accumulating of the role of zakat in the implementation of SDGs. Zakat has not only been empowering disadvantaged communities from the financial aspect but is also endorsing SDGs such as clean water and sanitation (SDG 6). However, this idea demands extensive scholarly discussion.

Against the backdrop detailed above, the present paper therefore aims to study the BAZNAS project for individual sanitation construction in underdeveloped rural zones in Indonesia. The discussion of this issue is critical to understanding the degree to which the practice has been contributing to improvements in the quality of life of the residents, notably to their efforts in accessing clean water and practicing hygiene. In addition, as will be elaborated in the next section, the existing scholarly works on zakat and SDGs have mainly dealt with conceptual and theoretical approaches, while studies exploring practical experiences of zakat institutions and discussing their efforts in endorsing SDG 6 remain scarce. This point, therefore, drives the authors to conduct this study.

The novelty of this paper lies in studying the perspectives of members of an underprivileged community who have received aid in the form of individual toilet construction. This work is expected to explain the practices of BAZNAS in endorsing SDG 6 and to be relevant to the related government agencies, zakat institutions, academics, industry professionals and global stakeholders in the SDGs.

This paper is organized as follows: Section II reviews the literature as a basis for the topic being discussed, Section III discusses the research methods employed and the remaining sections present discussion, conclusions, and recommendations.

\section{LITERATURE REVIEW}

\subsection{The Notion of SDGs and Their Recent Implementation in Indonesia}

The Sustainable Development Goals (SDGs) were initiated in 2012 during the United Nations conference in Rio de Janeiro, Brazil. This worldwide agenda 
replaced the poverty-alleviation undertakings of the Millennium Development Goals (MDGs) (UNDP). Furthermore, in September 2015, 193 countries, including Indonesia, signed the document 'Transforming Our World: The 2030 Agenda for Sustainable Development' in the general assembly of the United Nations in New York. Since January 2016, an agreed document referred to as 'the SDGs' has been in force.

The SDGs contain 17 goals along with 169 targets. The main ideas of these goals are concise aspirations to end poverty, pursue equity, and protect the Earth (UNDP; Panuluh \& Fitri, 2015; Imaz \& Sheinbaum, 2017). Recent updates to SDG implementation worldwide can be found in the SDG Index and Dashboards reports (Hudaefi, 2020). According to the 2020 report, Indonesia is ranked 101 out of 166 countries in the overall SDG index.

In a recent review of progress towards SDGs, Indonesia was said to be 'ontrack' for the goals of ending poverty (SDG 1), clean water and sanitation (SDG 6), decent work and economic growth (SDG 8), and climate action (SDG 13). For the zero hunger (SDG 2), good health and well-being (SDG 3), quality education (SDG 4 ), affordable and clean energy (SDG 7), industry innovation and infrastructure (SDG 9), and peace, justice and strong institutions (SDG 16), Indonesia's trend was captured as 'moderate increase.' For the SDGs of gender equality (SDG 5), sustainable cities and communities (SDG 11), life below water (SDG 14), and life on land (SDG 15), Indonesia's performance was characterized as 'stagnant'. Meanwhile, for the SDGs 10 and 12 (reduced inequalities and responsible consumption and production), no information of achievement was reported (Sachs et al., 2020). Figure 1 depicts the overall SDG performance of Indonesia in 2020.

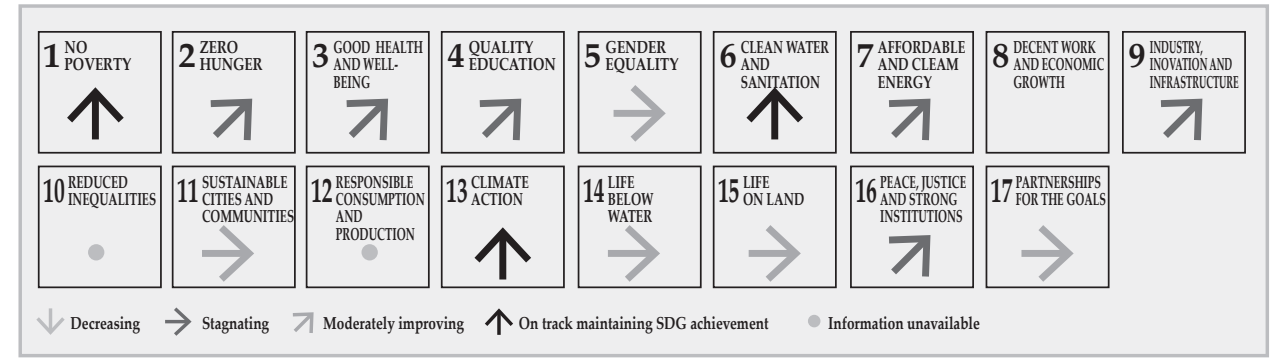

Source: Sachs, Schmidt-Traub, Kroll, Lafortune, \& Fuller, 2020

Figure 1.

Indonesia's SDG Trends in 2020

Massive efforts have been made by involved stakeholders towards the performance of Indonesia in recent SDG implementation. Zakat institutions are among these contributors and their critical role in community empowerment has been evidenced in numerous scholarly works. Studies which have looked at the subject of zakat and SDGs include Ariyani (2016), Asmalia, Kasri \& Ahsan (2018), Billah (2016), and Suprayitno, Aslam \& Harun (2017).

In general, these academic works have elaborated the role of zakat in poverty alleviation and human development and its potential to fund SDG projects. To the best of the authors' knowledge, scholarly articles presenting case studies of zakat 
institutions and focused on exploring their efforts in implementing a specific SDG remain scarce. On this basis, this paper aims to fill this gap in research.

\subsection{Previous Scholarly Works on Zakat and SDGs}

Apart from the the Indonesian Council of Ulama (or Majelis Ulama IndonesiaMUI) fatwa (legal opinion by Islamic jurists) No. 001/MUNAS/-IX/MUI/2015, which legalizes the use of zakat funds in financing SDG 6-related projects, the notion of zakat and SDGs in general has been of interest in recent scholarly articles. For example, Suprayitno et al. (2017) studied the impact of zakat on human development in five of Malaysia's states. The study found that local government had been utilizing zakat to stimulate human development and economic growth. They claimed that in the Malaysian case, zakat had been impacting positively on human development, implying implementation of SDGs in the local context (Suprayitno et al., 2017).

The fundamental similarity between zakat and SDGs has been addressed by Noor \& Pickup (2017). They mention that SDGs are representative of Islamic values, particularly in terms of the objectives of shariah law. In their discussion, Noor \& Pickup (2017) elaborate that the SDGs of zero poverty, no hunger, and inequality reduction are genuinely in line with the principles of zakat. Furthermore, Ismail \& Shaikh (2017) clarify the fundamental role of zakat and the implementation of SDGs. They argued that zakat has the potential to support the following SDGs:

- ending poverty and hunger,

- assisting global health and well-being,

- improving quality education,

- decent work and economic growth, and

- reducing income inequality (Ismail \& Shaikh, 2017).

Furthermore, Anindita \& Sidiq (2018) analysed the potential of zakat in achieving SDGs in the 34 provinces of Indonesia. They found that in the short term zakat can achieve the SDG of inequality reduction and promote the economic growth of each state. In addition, the potential of zakat funds to finance SDGrelated projects was addressed by Asmalia et al. (2018) and Harahap (2018). Their research respectively studied the possibility of zakat funding of SDGs and entrepreneurship. They argued such funding could assist the execution of SDGs, notably in transforming mustahik (zakat recipients, mostly underprivileged people) into muzakki (those who are obliged to pay zakat).

Taken together, the previous works have established recent discussion about the subjects of zakat and SDGs chiefly in the context of Indonesia. One may understand that these studies have been primarily theoretical explanations of zakat and SDGs while practical insights gained from the practices of zakat institutions in promoting a specific SDG remain few in number. Thus, given that contemporary practice in distributing zakat funds has been emerging in relation to SDG issues such as the project to construct private latrines (in line with SDG 6), this practice demands comprehensive discussion.

Against the background above, the present paper attempts to study the perspectives of underprivileged people who are the recipients of BAZNAS aid via the individual latrine construction project in Boyolali, Central Java, Indonesia. This case study is vital to developing an understanding of the degree to which zakat 
recipients have been benefitted by zakat distribution. The reason for selecting the BAZNAS project in this village is elaborated in the following section.

\subsection{BAZNAS Water and Sanitation Project in Boyolali, Indonesia}

The BAZNAS project in Boyolali is located in Kendel village, which is in an area of countryside with a population of around 6,894, some of whom experience rural poverty. The programme was implemented as a scheme between BAZNAS and the local government and was conducted in November 2018. The project covered assistance in the form of funding to construct toilets for 40 households.

Meanwhile, the local government contributed to the construction of a watersource facility by building a water tank and providing pump for water from the nearby river. The local government project was executed in advance of BAZNAS's assistance. Figure 1 illustrates this model of partnership.

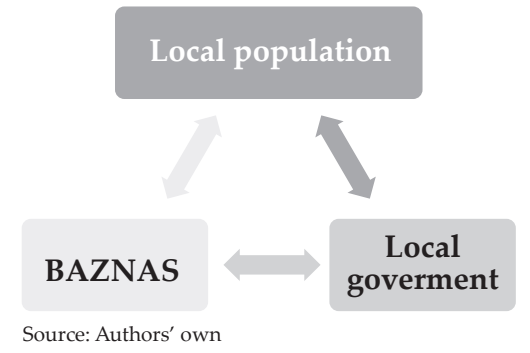

Figure 2.

Collaborative Water and Sanitation Programmes in Boyolali

Prior to the BAZNAS project, the local population had undertaken extra efforts to get access to sources of water. In the village, water sources are primarily the nearby river and rainwater. In the dry season the only option for local people to access water is thus to walk about four kilometres to the river. This situation has caused the residents to develop unhealthy traditions such as open defecation (OD). In consequence, diarrhoea has frequently affected local residents.

This situation for local residents in accessing water further underlines the importance of this study. That is, the degree to which zakat distribution in the form of individual latrine construction benefits local residents is deemed an essential subject for exploration. In order to drive the present discussion, this paper focuses on gaining authentic insights from the recipients of the project, and to this end the authors address the following question:

'What are the perspectives of the local population of Kendel in the wake of receiving aid for individual toilet construction from BAZNAS?'

\section{METHODOLOGY}

This paper employs a qualitative approach to study the perspective of zakat recipients assisted by the BAZNAS individual toilet construction project. Baehaqi, Birton \& Hudaefi (2020); Hudaefi et. al (2020); Hudaefi \& Heryani 
(2019); Hudaefi \& Jaswir (2019) and Hudaefi \& Noordin (2019) elaborate that a qualitative approach offers an effective way of characterizing and identifying a central phenomenon in which the variables involved require further exploration. Furthermore, Creswell (2012) and Plano Clark and Creswell (2015) explain that a qualitative method is best suited to exploring variables for describing a central phenomenon.

\subsection{Qualitative Case Study}

The authors carried out a case study of the BAZNAS toilet construction project in Kendel village, Boyolali, Central Java, Indonesia. Despite findings from case studies not being generalizable, this approach is important for examining data from particular and limited geographical areas (Zainal, 2007). In this research, a descriptive case study was conducted to describe the perspectives of local residents of Kendel village, enabling the authors to collect authentic insights.

\subsubsection{Observation and Interviews}

In conducting the case study, this paper employed participant observation and semi-structured interviews as methods of collecting relevant data. Participant observation involves a researcher interacting directly with people to gather the information required during a study (Jorgensen, 2015). Meanwhile, a semistructured interview is a verbal interchange which allows a research interviewer to engage a flexible technique in deciding on the general structure of questions and then developing those questions during an interview (Drever, 1995; Longhurst, 2016).

In this paper, the authors participated in directly observing the 40 constructed toilets in Kendel village to gain authentic insights into the contribution of the toilets to the local community. Following this, the authors carried out semi-structured interviews with selected participants to obtain relevant information from the main actors. The participants were chosen using a purposive sampling method, allowing the authors to decide the individuals best positioned to provide the information required (Creswell, 2012; Sekaran, 2003). Figure 3 depicts the model of research.

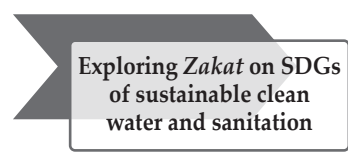

Source: Prepared by authors

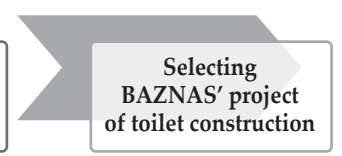

Figure 3.

Model of Research

\subsubsection{Findings from observations}

A three-day observation from 22 to 24 May 2019 was conducted in Kendel. This duration of observation was deemed essential to describe the existing situation (Kawulich, 2005), so as to understand the degree to which the project had benefitted residents. The observer team comprised; 
- $\quad$ researchers from BAZNAS Centre of Strategic Studies $(n=1)$,

- officers of BAZNAS Division of Monitoring and Evaluation (DME) $(n=1)$, and

- $\quad$ officers of BAZNAS Boyolali $(n=1)$.

The first-day observation procedure began by reviewing the documents of the recipients to develop an understanding of their circumstances before they received the assistance. On the second day, the team directly visited the 40 houses in the village in which the project was executed. On the final day, interviews with the selected participants were carried out to support the findings from the observations.

From observing the recipients' houses directly, the team was able ascertain that 39 toilets had been effectively utilized by the receiving households since January 2019. During the observation, the team noticed some improvements in the quality of life of the local inhabitants. That is, in contrast to the zakat recipients' houses, which were mostly built from wood - in local perspectives seen as an indication of low-income families, their newly constructed toilets were built from cement and bricks, representing a modern and well-constructed type of building.

As seen from the observations carried out, the team assumed an upgrade in the quality of life of the recipients, notably in their practicing of healthier sanitation. However, further justification is required in a methodological work of this type, and to supply this the team executed semi-structured interviews on the following day to reveal the main actors' perspectives.

\subsubsection{Findings from the Interviews}

The seven participants $(n=7)$ consisted of a local administrator $(n=1)$ and six local people receiving assistance $(n=6)$ were engaged during the interviews. In a qualitative study, the validity of number of participants used for in-depth interviews is subjective. Dworkin (2012) explains that five to fifty participants are adequate for face-to-face interviews, and thus the seven people selected are deemed sufficient for this study.

The purpose of interviewing the officer from local government was to gain relevant information about the topic being discussed from the governmental level. Meanwhile, talking face-to-face with recipients aimed at exploring their perspectives on the assistance given to them. The details of the interviewees are as presented in Table 1.

Table 1.

Demographics of Participants

\begin{tabular}{ccc}
\hline No & Participants & Designation \\
\hline 1 & Interviewee A & Local government \\
2 & Interviewee B & Aid recipients \\
3 & Interviewee C & \\
4 & Interviewee D & \\
5 & Interviewee E & \\
6 & Interviewee F & \\
7 & Interviewee G &
\end{tabular}


The interviews were conducted in the mosque following afternoon prayers. Verbal communication was in the local language (Bahasa Jawa) and was recorded digitally. The audio was then transcribed verbatim manually into Microsoft Word for data analysis. In total, the semi-structured interviews with the seven participants took about two hours.

The team started the interview with the following question:

Q1: could you explain the practice of accessing water and sanitation performed by the local people here, particularly before getting assistance from $B A Z N A S$ ?

Responding to this question, the representative from the local government, who is the headman of Kendel village $(n=1)$ stated the following:

Firstly, regarding access to water, I'd say there are two main water sources here, the river and water springs. Prior to BAZNAS donating to construct the toilets, there is assistance from the government, which is a public water tank along with a machine pumping water to it. This shared facility is built nearby the residents' houses. So, there was no significant obstacle for water access. However, there was an issue of sanitation before the aid from BAZNAS. Most of the countrypeoples's toilet facilities were inappropriate and unsafe [...]

The team then further developed the interview to expand on the answer from Interviewee $\mathrm{A}(n=1)$ as above. He was asked in detail about former conditions of individual sanitation facilities among the local population. In this regard, the same participant $(n=1)$ explained as follows:

[...] previously, the lavatory facility in most of our residents' houses was built improperly. It had no roof as it was only, like, one-meter square toilet with the wall made from plastic and the floor from wood. These were materials which were not fit as a toilet construction and were unsafe. In many cases, some residents did not build a standard septic tank, such as one with systematic closed-hole excavation. So, when it came to defecation, the faeces flowed directly to the bunker below the lavatory. It was an unhealthy practice [...]

Furthermore, the team validated such issues with the interviewees who were local residents $(n=6)$. In this regard, they authenticated the information given above. Some of them $(n=3)$ with no hesitation informed the team about non-ideal practices of defecation, with responses as follows:

[...] yes, last time (before getting assisted by BAZNAS project), some of us did not have proper toilet facilities. Some of us had practiced open defecation close to the river, which is one of the primary water sources for us here [...]

In view of getting information about previous water access and the practice of sanitation before the BAZNAS project as indicated by the above conversation, the team then proceeded to the next queries. The team were concerned with the benefits of the project and so then asked: 
Q2: what do you think about the contribution of the BAZNAS project to the local community here?

In response to this inquiry, the respondents $(n=7)$ all voiced positive standpoints. The information from the headman $(n=1)$ may best represent their answers. He stated as follows:

I'd say after BAZNAS providing its assistance of toilet construction to some residents of our village, I've seen and experienced some significant changes. Most of our residents have now their own sanitation facilities attached to their houses, which are standard and appropriate. With having these, the former practice of open defecation, I can guarantee, has been significantly declining $[\ldots]$

Moving from talking with the representative of local government, the tête-àtête continued with the local population $(n=6)$ to confirm the information with specific evidence. The team asked the following question:

Q3: What do you think about the benefit of the BAZNAS project for you and your family?

In response to this question, the interviewees $(n=6)$ similarly answered in terms of the benefits of having appropriate access to water and better latrine facilities. The response from Interviewee F can best represent their experiences:

[...] well, I'd say I have genuinely benefitted. Some of us, who are (mostly) an underprivileged community, have now access to clean water and own a standard sanitation facility in our houses. Also, I am saying that local people are now getting healthier [...]

Following the interviewee's response as above, the team narrowed the final question to health-related matters, to investigate whether the BAZNAS programme had contributed to improving the community's health:

Q4: In your experience, do you see that the BAZNAS project has helped to improve the health of the local population here?

The interviewees $(n=7)$ all stated that the programme was impacting on the improvement in health of the local population. This is evident from an interviewee's claim that the number of people affected by diarrhoea had been reducing. The result from talking with the headman $(n=1)$ may best explain their perspective. He said as follows:

[...] absolutely, yes, I do. Before the assistance conducted in our village, diseases such as diarrhoea had been frequently affecting our local residents. Such condition is due to the practicing of open defecation near the river. So, when it comes to the rainy season, many of our countrymen, especially children, are 
affected by diarrhoea. This is because they are utilizing the water from the river [...] following the implementation of the (BAZNAS) programmes, the health condition of Kendel's population is getting better [...] I can confirm the number of those who are affected by diarrhoea has been decreasing [...]

With the last conversation as above, the team was of the view that satisfactory information to answer the research question had been obtained and the discussion was concluded. In brief, by conducting observation and semi-structured interviews with the main actors, reliable data was gained to answer the issue being discussed. From observing directly, the authors were able to ascertain the number of toilets in active use and from conversing directly with the recipients, authentic insight into their perspectives were documented systematically.

\section{DISCUSSION OF FINDINGS}

This study set out to explore the perspectives of recipients of zakat assisted by the BAZNAS individual toilet construction project, in order to understand the extent to which the distributed zakat funding had positively impacted on its recipients. The paper presents a case study of the sanitation project of BAZNAS in Boyolali, Central Java, Indonesia. The findings clarify the perspectives of these zakat recipients, notably the improvements in their quality of life since receiving the assistance. The findings also provide a description of the role of zakat in supporting the implementation of SDG 6.

During the study, direct observation and semi-structured interviews with the primary informants were carried out, as documented and explained above. The present findings indicate that such BAZNAS project has upgraded the quality of life of the local population, notably in the context of hygiene practices and access to clean water.

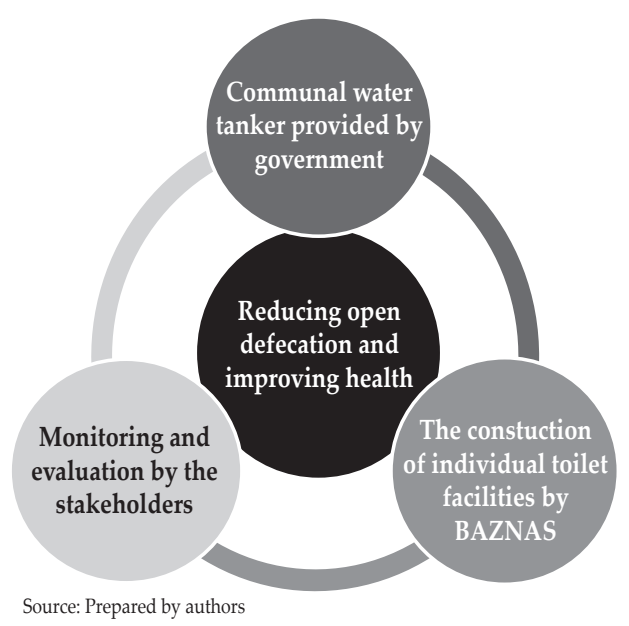

Figure 4. The Findings 


\subsection{Reducing the Practice of OD}

The issue of OD occurs not only in Indonesia, but also in other developing countries such as Cambodia, India, Tanzania and the Sub-Saharan African countries. Recent worldwide agendas, such as the Water, Sanitation and Hygiene (WASH) project of The United Nations Children's Fund (UNICEF) and SDG 6, aim at tackling this issue. These global calls for change require collaborative work among related stakeholders to solve this acute problem. In this study, the evidence from the project of BAZNAS in Kendel village may be reflective of the efforts of zakat institutions in lessening the practice of OD.

Similar to other developing countries, poverty in Indonesia results in the population using inappropriate latrines. The economic condition of a country is seen to be strongly correlated with improvements in its national sanitation conditions (Morella, Foster \& Banerjee, 2008), and thus efforts to decrease the practice of OD demand collective work. In this regard, Obeng et al. (2015) highlighted the need for low-income families in Ghana to have indoor domestic toilets and proposed a communal latrine and the establishment of related policy to mitigate the issue of OD. The same issue also occurs in underprivileged rural Tanzanian households. In this case, Sara \& Graham (2014) mentioned the inability of local families to construct their own private latrines due to cost, and recommended collaborative works for building a sanitation facility (Sara \& Graham, 2014).

In India, Jayakumar, Das \& Srivastava (2019) studied the way a local NonGovernmental Organization (NGO) used design thinking (DT) to solving water scarcity in an Indian village. They found that the NGO that employed DT was able to unravel the issues around the water shortage there. In another study, Coffey et al. (2014) argued that some local Indian people would continue to practice OD even if the government built toilets inside their houses. They believe the issue can best be mitigated by establishing an administrative policy to support the use of private latrines (Coffey et al., 2014).

It is therefore clear that poverty has been a significant causal factor in the OD practices existing in developing countries. Scholarly works have extensively discussed potential intellectual solutions to this problem. This present study provides evidence from the BAZNAS assistance with individual lavatory construction in Kendel, an underdeveloped village in Boyolali Region of Indonesia. The evidence from the study goes some way to explaining that such collaborative work among related stakeholders has been successful in promoting proper sanitation and reducing the practice of OD in the community. From this finding, it can be concluded that the establishment of joint programmes among stakeholders is important in achieving ideal sanitation practices.

\subsection{Improving the Health of Local Populations}

The most notable finding from our discussions with aid recipients in Kendel village is the documentation of authentic information explaining the health conditions of the local population. The sanitation project carried out by BAZNAS was claimed by respondents to have positively impacted on the health of residents. The statement from the headman of the village firmly suggests that the number of local residents who are affected by diarrhoea has been reducing. Even so, such evidence demands further quantitative investigation in order to establish positive evidence. 
The present findings do, however, to some degree confirm the notion that better sanitation leads to better health, and that proper sanitation is the primary driver for public health (Jong-Wook, 2004). Mara, Lane, Scott, \& Trouba (2010) elaborated upon satisfactory sanitation along with good water supply and hygiene being fundamental to good health, and to social and economic development. They raised the issue of complexity in the topic of sanitation and proposed three strategies for success in bringing about improvement:

- political leadership,

- decentralization of infrastructure development based on local demands, and

- the involvement of the health sector (Mara et al., 2010).

Moreover, the World Bank (2003) has explained the ways in which water, health and sanitation are interconnected. It states that hepatitis, typhoid, cholera, dysentery, and diarrhoea have strong correlation with the consumption of contaminated water. The sustainability of clean water and sanitation is, in fact, more than just advantageous for people's health. The World Bank (2003) explains the further benefits of the WaterAid programme of 2001 in India. Among the impacts claimed were positive effects on community unity and self-esteem, and reductions in conflict (World Bank, 2003).

Taken together, the findings from this case study of the aid provided by BAZNAS in Kendel village may highlight the correlations between health, water and sanitation. In addition, these findings establish the implication of the necessity for collaborative works among zakat institutions and local governments in developing ideal sanitation practices. The evidence above, moreover, is synonymous with zakat institutions' efforts in promoting UNDP SDG 6.

\section{CONCLUSIONS AND RECOMMENDATIONS}

\subsection{Conclusions}

At the beginning of this paper, the authors argued that this innovation in distributing zakat by BAZNAS not only promoted SDGs 1 and 2 (which are closely related with zakat principles) but also SDG 6: clean water and sanitation. In order to support this claim, the present study conducted a qualitative case study of the BAZNAS programme delivered in Kendel village, Boyolali, Indonesia, using observation and semi-structured interviews to collect data.

The findings provide the recipients' perspectives in the wake of receiving assistance from BAZNAS in the form of the project for individual latrine construction. The findings may validate the positivist view that health, water and sanitation are correlated. In addition, the ways in which the BAZNAS project in Kendal village may support efforts in promoting UNDP SDG 6.

\subsection{Recommendations}

\subsubsection{Recommendations for Related Institutions and Regulators}

Given that the evidence from Kendel village is an example of collaborative works between a zakat institution and a local administration, several recommendations are applicable to zakat institutions and regulators. This work provides hands-on knowledge, as depicted in Figure 4, and its findings can provide the basis for an 
ideal model for implementation in other underdeveloped villages in Indonesia aimed at achieving ideal sanitation practices.

Furthermore, it is suggested that the Indonesian government should map water sources and sanitation issues for each province. This is practically important because each village in Indonesia may experience different issues with regard to water and sanitation. The purpose of such mapping is to faster achieve the implementation of SDG 6.

\subsubsection{Recommendations for Future Studies}

Investigation of the relationship among health, water and sanitation requires a multidisciplinary approach. The present study lacks validity in terms of robust methods, particularly in terms of the expert involvement of those from the health field. Therefore, future work may collaborate with health sciences researchers and gather more evidence from other zakat institutions to study whether zakat distribution for water and sanitation facilities solves the health-related issues in the respective areas involved. In addition, future work may employ methods such as Delphi, analytic network processing (ANP) and structural equation modelling (SEM) to establish more robust evidence.

\section{REFERENCES}

Abd. Wahab, N., Zainol, Z., \& Abu Bakar, M. (2017). Towards Developing Service Quality Index for Zakat Institutions. Journal of Islamic Accounting and Business Research, 8(3), 326-333. https://doi.org/10.1108/JIABR-09-2015-0040.

Abdullah, M., \& Suhaib, A. Q. (2011). The Impact of Zakat on Social life of Muslim Society. Pakistan Journal of Islamic Research, 8, 85-91. Retrieved from https:// www.bzu.edu.pk/PJIR/eng8Abdullah\&AbdulQuddusSuhaib.pdf.

Anindita, S. F., \& Sidiq, S. (2018). Analisis Potensi Zakat dalam Pencapaian Program SDGs di 34 Provinsi di Indonesia [Analysis of the Potential of Zakat in Achieving the SDGs Program in 34 Provinces in Indonesia]. In A. Tohirin, A. Widarjono, A. Affandi, A. H. M. Noor, K. Susilabudi, SE., \& M. S. A. Rasul (Eds.), 6th Southeast Asia International Islamic Philanthropy Conference 2018 (pp. 27-36). Yogyakarta. Retrieved from https://dspace.uii.ac.id/ bitstream/handle/123456789/8277/Full Proceeding_SEAIIPC 2018_1605_7. pdf? sequence $=2 \&$ isAllowed=y\#page $=35$.

Ariyani, N. (2016). Zakat as a Sustainable and Effective Strategy for Poverty Alleviation: From the Perspective of a Multi-Dimensional Analysis. International Journal of Zakat , 1(1), 88-106. Retrieved from https://ijazbaznas.com/index. php/journal/article/view/9.

Asmalia, S., Kasri, R. A., \& Ahsan, A. (2018). Exploring the Potential of Zakah for Supporting Realization of Sustainable Development Goals (SDGs) in Indonesia. International Journal of Zakat, 3(4), 51-69. Retrieved from https:// ijazbaznas.com/index.php/journal/article/view/106.

Baehaqi, A., Birton, M.N.A. \& Hudaefi, F.A. (2020). Time Value of Money in Islamic Accounting Practice: A Critical Analysis from Maqāsid al-Sharīıah. Journal of Islamic Accounting and Business Research. https://doi.org/10.1108/ JIABR-09-2018-0155. 
Billah, M. M. (2016). Creating an Eco-Sustainable Community: The Role of Zakat. International Journal of Zakat, 1(1), 1-16. Retrieved from https://ijazbaznas.com/ index.php/journal/article/view/3.

Coffey, D., Gupta, A., Hathi, P., Khurana, N., Spears, D., Srivastav, N., \& Vyas, S. (2014). Revealed Preference for Open Defecation Evidence from a New Survey in Rural North India. Economic E Political Weekly, xlix(38), 43-55. Retrieved from https://cpb-us-w2.wpmucdn.com/web.sas.upenn.edu/dist/1/140/files/2016/06/ SA_XLIX_38_200914_Diane_Coffey_Aashish_Gupta_Payal_Hathi_Nidhi_ Khurana_Dean_Spears_Nikhil_Srivastav_Sangita_Vyas-11rzpdv.pdf.

Creswell, J. W. (2012a). Educational Research: Planning, Conducting, and Evaluating Quantitative and Qualitative Research. Educational Research (4th ed.). https://doi. org/10.1017/CBO9781107415324.004.

Creswell, J. W. (2012b). Educational Research: Planning, Conducting and Evaluating Quantitative and Qualitative Research (4th ed.) Boston, USA: Pearson.

Drever, E. (1995). Using Semi-Structured Interviews in Small-Scale Research. A Teacher's Guide. Scottish Council for Research in Education, Edinburgh. Retrieved from https://eric.ed.gov/?id=ED394990.

Dworkin, S. L. (2012). Sample Size Policy for Qualitative Studies Using In-Depth Interviews. Archives of Sexual Behavior, 41(6), 1319-1320. https://doi.org/10.1007/ s10508-012-0016-6.

Harahap, L. R. (2018). Zakat Fund As The Starting Point of Entrepreneurship in Order to Alleviate Poverty (SDGs Issue). Global Review of Islamic Economics and Business, 6(1), 63-74. Retrieved from http://ejournal.uin-suka.ac.id/febi/grieb/ article/view/061-05/604.

Hudaefi, F.A. (2020). How does Islamic fintech promote the SDGs? Qualitative evidence from Indonesia. Qualitative Research in Financial Markets, 12 (4), 353366. https://doi.org/10.1108/QRFM-05-2019-0058.

Hudaefi, F. A., Beik, I.S., Zaenal, M. H., Choirin, M., Farchatunnisa, H., \& Junari, U. L. (2020). How Does Zakat Institution Respond to Fintech? Evidence From BAZNAS, Indonesia. International Journal of Zakat and Islamic Philanthropy, 2 (1), 32-40. http://journal.zakatkedah.com.my/wp-content/uploads/2020/03/ Vol2_1_4_20.pdf.

Hudaefi, F. A., \& Heryani, N. (2019). The Practice of Local Economic Development and Maqāsid al-Sharī‘ah: Evidence From a Boarding School in West Java, Indonesia. International Journal of Islamic and Middle Eastern Finance and Management, 12(5), 625-642. https://doi.org/10.1108/IMEFM-08-2018-0279.

Hudaefi, F. A., \& Jaswir, I. (2019). Halal Governance in Indonesia: Theory, Current Practices, and Related Issues. Journal of Islamic Monetary Economics and Finance, 5(1), 89-116. https://doi.org/10.21098/jimf.v5i1.1049

Hudaefi, F.A. \& Noordin, K. (2019). Harmonizing and Constructing an Integrated Maqāsid al-Sharī'ah Index for Measuring the Performance of Islamic Banks. ISRA International Journal of Islamic Finance, 11(2), 282-302. https://doi. org/10.1108/IJIF-01-2018-0003.

Imaz, M., \& Sheinbaum, C. (2017). Science and Technology in the Framework of the Sustainable Development Goals. World Journal of Science, Technology and Sustainable Development, 14(1), 2-17. https://doi.org/10.1108/ WJSTSD-04-2016-0030. 
Ismail, A. G., \& Shaikh, S. A. (2017). Where Is the Place for Zakat in Sustainable Development Goals? (IESTAC Working Paper Series No. 4). Bangi. Retrieved from https://www.researchgate.net/publication/321208923.

Jayakumar, T., Das, K., \& Srivastava, N. (2019). Design Thinking: A Working Strategy for the Third Sector. Journal of Business Strategy, JBS-11-2018-0195. https://doi.org/10.1108/JBS-11-2018-0195.

Jong-Wook, L. (2004). Water, Sanitation and Hygiene Links to Health. Retrieved from https://www.who.int/water_sanitation_health/publications/facts2004/en/.

Jorgensen, D. L. (2015). Participant Observation. In Emerging Trends in the Social and Behavioral Sciences (pp. 1-15). Hoboken, NJ, USA: John Wiley \& Sons, Inc. https://doi.org/10.1002/9781118900772.etrds0247.

Kawulich, B. B. (2005). Participant Observation as a Data Collection Method. Forum: Qualitative Social Research, 6(2). Retrieved from http://nbn-resolving.de/ urn:nbn:de:0114-fqs0502430.

Longhurst, R. (2016). Semi-Structured Interviews and Focus Groups. In N. Clifford, M. Cope, T. Gillespie, \& S. French (Eds.), Key Methods in Geography (3rd ed., pp. 143-153). London: SAGE Publications.

Mara, D., Lane, J., Scott, B., \& Trouba, D. (2010). Sanitation and Health. PLoS Medicine, 7(11). https://doi.org/10.1371/journal.pmed.1000363.

Morella, E., Foster, V., \& Banerjee, S. G. (2008). Climbing the Ladder: The State of Sanitation in Sub-Saharan Africa. AICD Background Paper 13. Washington D.C., USA: World bank. Retrieved from www.worldbank.org.

Noor, Z., \& Pickup, F. (2017). The Role of Zakat in Supporting the Sustainable Development Goals. Retrieved from https://s3.amazonaws.com/academia.edu. documents/53568002/INS-Zakat-English.pdf?AWSAccessKeyId=AKIAIWOW YYGZ2Y53UL3A\&Expires=1559551016\&Signature=trI11F1EnDaAXdGBeIUc 4ImdWmE\%3D\&response-content-disposition=inline\%3B filename\%3DThe_ role_of_zakat_in_support.

Obeng, P. A., Keraita, B., Oduro-Kwarteng, S., Bregnhøj, H., Abaidoo, R. C., \& Konradsen, F. (2015). The Latrine Ownership Ladder: A Conceptual Framework for Enhancing Sanitation Uptake in Low-Income Peri-Urban Settings. Management of Environmental Quality: An International Journal, 26(5), 752-763. https://doi.org/10.1108/MEQ-05-2014-0079.

Panuluh, S., \& Fitri, M. R. (2015). Perkembangan Pelaksanaan Sustainable Development Goals (SDGs) di Indonesia [Development of the Implementation of Sustainable Development Goals (SDGs) in Indonesia]. Retrieved from https://www. sdg2030indonesia.org/an-component/media/upload-book/Briefing_paper_ No_1_SDGS_-2016-Meila_Sekar.pdf.

Plano Clark, V. L., \& Creswell, J. W. (2015). Understanding Research: A Consumer's Guide. Retrieved from https://doi.org/13-978-0-13-158389-4.

Sachs, J., Schmidt-Traub, G., Kroll, C., Lafortune, G., Fuller, G., \& Woelm, F. (2020). The Sustainable Development Goals and COVID-19. Sustainable Development Report 2020. Cambridge: Cambridge University Press.

Sara, S., \& Graham, J. (2014). Ending Open Defecation in Rural Tanzania: Which Factors Facilitate Latrine Adoption? International Journal of Environmental Research and Public Health, 11(9), 9854-9870. https://doi.org/10.3390/ ijerph110909854. 
Sekaran, U. (2003). Research Methods for Business: A Skill-Building Approach, fourth edition. New York, USA: John Wiley \& Sons.

Suprayitno, E., Aslam, M., \& Harun, A. (2017). Zakat and SDGs: Impact Zakat on Human Development in the Five States of Malaysia. International Journal of Zakat, 2(1), 61-69. Retrieved from https://ijazbaznas.com/index.php/journal/ article/view/15.

UNDP (n.d.). Sustainable Development Goals UNDP. Retrieved from https:// www.undp.org/content/undp/en/home/sustainable-development-goals.html

World Bank. (2003). Water, Sanitation \& Hygiene. Retrieved from http://web. worldbank.org/archive/website01213/WEB/0_CO-75.HTM.

Zainal, Z. (2007). Case Study as a Research Method. Jurnal Kemanusiaan, 5(1), 1-6. Retrieved from https://jurnalkemanusiaan.utm.my/index.php/kemanusiaan/ article/view/165. 